\title{
A tutela jurisdicional dos crimes ambientais ocorridos na comarca de Rubiataba, Goiás, entre o período de 2012 a 2018
}

The jurisdictional guarantee of environmental crimes occurred in Rubiataba, Goiás, Brazil, from 2012 to 2018

La garantía jurisdiccional de delitos ambientales ocurridos en

Rubiataba, Goiás, Brasil, entre los años de 2012 a 2018

Aparecida Imaculada de Jesus Sainça ${ }^{1}$ Juliana Heloisa Pinê Américo-Pinheiro ${ }^{2}$ Evandro Roberto Tagliaferro ${ }^{3}$ Cristina Veloso de Castro ${ }^{4}$

${ }^{1}$ Mestre em Ciências Ambientais pela Universidade Brasil (UNIVBRASIL). Graduado em Direito pela Faculdade de Ciências e Educação de Rubiataba (FACER). E-mail: aijsainca@tjgo.jus.br, ORCID: https://orcid.org/0000-0002-6848-289X

${ }^{2}$ Doutora em Aquicultura na área de Biologia Aquática e Bióloga pela Universidade Estadual Paulista Júlio de Mesquita Filho (UNESP). Professora titular do Programa de PósGraduação Stricto Sensu em Ciências Ambientais da Universidade Brasil (UNIVBRASIL). E-mail: americo.ju@gmail.com, ORCID: http://orcid.org/0000-0001-6252-828X

${ }^{3}$ Doutor em Administração Empresarial e Comércio Internacional pela Universidade de Extremadura (UNEX), Espanha. Engenheiro civil. Professor titular do Programa de Pós-Graduação Stricto Sensu em Ciências Ambientais da Universidade Brasil (UNIVBRASIL). E-mail: tagliaferro@etagli.com.br, ORCID: https://orcid.org/0000-0003-2557-031X

${ }^{4}$ Doutora em Sistema Constitucional de Garantias de Direito pelo Instituto Toledo de Ensino (ITE). Professora titular do Programa de PósGraduação Stricto Sensu em Ciências Ambientais da Universidade Brasil (UNIVBRASIL). E-mail: cristinavelosodecastro@gmail.com, ORCID: http://orcid.org/0000-0002-3016-0326 
Resumo: Uma alteração no meio ambiente, produto de ação ou atividade antrópica, gera impactos ao ser humano è natureza, passíveis de criminalização. Esta pesquisa visou descrever a aplicação da lei penal aos crimes ambientais em Rubiataba, Goiás, entre 2012 e 2018, identificar denúncias e consequentes ações penais ambientais no período e avaliar a eficácia da norma legal, da tutela jurisdicional dos crimes ambientais em relação à sustentabilidade. Serviu-se da pesquisa bibliográfica e documental, realizada na Escrivania Criminal da Comarca de Rubiataba. Foram identificados 23 processos por crimes ambientais. Foram propostos, pelo Ministério Público, transação penal, suspensão condicional e requerimento para arquivamento de processos por ausência de justa causa para a propositura da Ação Penal e diligências à Delegacia de Polícia. Os resultados evidenciaram que o oferecimento da transação penal nos crimes ambientais envolve o direito de pagamento de pena pecuniária, destinada a entidades beneficentes não relacionadas à preservação ambiental.

Palavras-chave: destruição de florestas; meio ambiente; normatização; penalidades; suspensão.

\begin{abstract}
A change in the environment, as a result of human action or activity, generates impacts on man and nature, liable to criminalization. This research aimed to describe the application of the criminal laws to environmental crimes in Rubiataba, Goiás, between 2012 and 2018 , to identify complaints and consequent environmental criminal actions in the period, and to evaluate the effectiveness of the legal norms, the jurisdictional protection of environmental crimes concerning sustainability. It used bibliographical and documentary research, this last one carried out in the Criminal Registry of the District of Rubiataba. They identified 23 processes for environmental crimes. The Public Prosecutor's Office proposed a criminal transaction, a conditional suspension, and a request to close cases for the absence of just cause for the proposal of the Criminal Action and diligences to the Police Station. The results showed that the offer of the criminal transaction for environmental crimes involves the right to paying a financial penalty, destined for charities not related to environmental preservation.
\end{abstract}

Keywords: destruction of forests; environment; standardization; penalties; suspension.

Resumen: Un cambio en el medio ambiente, producto de la acción o actividad humana, genera impactos sobre el hombre y la naturaleza, susceptibles de criminalización. Esta investigación tuvo como objetivo describir la aplicación de la ley penal a los delitos ambientales en Rubiataba, Goiás, entre 2012 y 2018, identificar quejas y acciones criminales ambientales en el período y evaluar la efectividad de normas legales, la protección jurisdiccional de los delitos ambientales en relación con la sostenibilidad. Se utilizó investigación bibliográfica y documental, realizada en el Registro Penal del Distrito de Rubiataba. Se identificaron 23 demandas por delitos ambientales. La Fiscalía propuso una transacción penal, suspensión condicional y una solicitud para cerrar casos por falta de causa justa para la presentación de la Acción Criminal y la debida diligencia a la Estación de Policía. Los resultados mostraron que la oferta de la transacción criminal en delitos ambientales implica el derecho a pagar una multa financiera, destinada a organizaciones benéficas no relacionadas con la preservación del medio ambiente.

Palabras clave: destrucción de florestas; medio ambiente; estandarización; sanciones; suspensión. 


\section{INTRODUÇÃO}

É crescente a preocupação com a proteção ao meio ambiente. Várias organizações não governamentais o defendem contra atos lesivos praticados por quem quer que seja. Nas décadas de 1980 e 1990, a consciência e discussão sobre a proteção da natureza expandiram no Brasil. No que tange à sua proteção, livros e artigos doutrinários foram publicados e inúmeras leis foram criadas nesse período. O Artigo 225 da Constituição Federal de 1988 (BRASIL, 1998) prevê o direito ao meio ambiente ecologicamente equilibrado, e o uso comum do povo é condição mínima para a dignidade da pessoa humana.

O Direito Ambiental é a ciência que estuda a relação entre a sociedade humana e o meio ambiente. O ser humano necessita utilizar os recursos naturais como matéria-prima para o desenvolvimento; no entanto, alguns desses recursos essenciais à vida não são renováveis.

Assim, a Constituição estabelece uma relação de sustentabilidade para permitir que o ser humano utilize o meio ambiente, mas, ao mesmo tempo, obriga-o a preservar e recuperar quando necessário. Para isso, aplica sanções previamente estabelecidas, a fim de garantir às gerações presentes e futuras uma sadia qualidade de vida. As sanções estabelecidas para preservação ambiental são de responsabilidade civil, responsabilidade administrativa e responsabilidade penal.

O direito penal é um mecanismo utilizado como ultima ratio para punir o agente que comete crime contra o meio ambiente. Entretanto, este mecanismo jurídico, muitas vezes, torna-se ineficaz para a preservação e proteção do bem jurídico tutelado. A preservação do ambiente natural é, também, preocupação das políticas públicas mundiais, pois os danos ambientais trazem consequências irreparáveis à humanidade.

A crescente degradação do meio ambiente na região do Município de Rubiataba em Goiás motivou a presente pesquisa, que busca analisar a tutela jurisdicional dos crimes ambientais ocorridos no período compreendido entre os anos de 2012 e 2018.

O objetivo deste trabalho foi verificar se a tutela jurisdicional penal ambiental está sendo provocada e, quando provocada, se a resposta penal 
aplicada, consistente em pagamento de pena pecuniária, é revestida em favor do meio ambiente degradado.

\section{BREVE HISTÓRICO SOBRE A TUTELA JURISDICIONAL DOS CRIMES AMBIENTAIS NO BRASIL}

A proteção jurídica do meio ambiente no Brasil pode ser dividida em três períodos. O primeiro período começa com o descobrimento do Brasil em 1500 e termina em 1808. O segundo período se inicia em 1808, caracterizado pela exploração desregrada do meio ambiente, e as questões eram solucionadas pelo código civil. Tutelava-se somente aquilo que tivesse interesse econômico. O terceiro período inicia-se com a criação da Lei da Política Nacional do Meio Ambiente (SIRVINSKAS, 2015). Neste contexto, a Lei n. 6.938/1981 (BRASIL, 1981) propôs proteger de maneira integral o meio ambiente por um sistema ecológico integrado.

No Brasil, o conceito de meio ambiente, do ponto de vista legal, é tratado na Lei 6.938/81, em seu art. 3‥ Segundo esta lei, entende-se por meio ambiente "[...] o conjunto de condições, leis, influências e interações de ordem física, química e biológica, que permite, abriga e rege a vida em todas as suas formas" (BRASIL, 1981). A Constituição Federal de 1988 ratificou a proteção sadia da qualidade de vida do ser humano, visando a um meio ambiente ecologicamente equilibrado (BRASIL, 1988).

Silva (2019) corrobora que o meio ambiente é a interação de elementos naturais, artificiais e culturais, que proporcionam o equilíbrio no desenvolvimento da vida em todas as suas formas. Assim, é importante observar os instrumentos públicos de proteção, preservação e reparação do meio ambiente.

\section{A TUTELA PENAL DO MEIO AMBIENTE}

O ser humano, continuamente, degrada a natureza, não obstante as leis ambientais prevejam sanções administrativas e judiciais. Diante de tantas agressões, surge a necessidade indispensável da tutela penal ambiental, posto que as medidas aplicadas nas esferas administrativa e civil não surtem os efeitos esperados. Surge, então, o direito ambiental, codificado na 
A tutela jurisdicional dos crimes ambientais ocorridos na comarca de Rubiataba, Goiás, entre o período de 2012 a 2018

Lei n. 9.605/98 (BRASIL, 1998), conhecida como Lei de Crimes Ambientais, que é um instrumento fundamental à tutela penal ambiental, uma vez que coíbe, intimida e repreende as pessoas físicas e jurídicas que cometem delitos ambientais.

Sobre a importância da tutela penal, segundo Sirvinskas (2015, p. 887), "[...] a sua proteção não deve restringir-se a uma ou várias pessoas de um país, mas, sim, a todos os países. Um crime ambiental poderá repercutir em diversos países do mundo como, por exemplo, um desastre nuclear ou a poluição de um rio que atravessa alguns países".

A medida penal tem a finalidade de prevenir e reprimir condutas praticadas contra a natureza. De acordo com Ferreira (1995, p. 13): "Tal tutela deve ser a ultima ratio, ou seja, só depois de esgotarem os mecanismos intimidatórios (civil e administrativo) é que se procurará a eficácia punitiva na esfera penal". Dessa forma, para o direito penal, a tutela penal deve ser reservada à lei, partindo-se do princípio da intervenção mínima no Estado Democrático de Direito.

De acordo com Bitencourt (2015, p. 54):

O princípio da intervenção mínima, também conhecido como ultima ratio, orienta e limita o poder incriminador do Estado, preconizando que a criminalização de uma conduta só se legitima se constituir meio necessário para a prevenção de ataques contra bens jurídicos importantes. Ademais, se outras formas de sanção ou outros meios de controle social se revelarem suficientes para a tutela desse bem, a sua criminalização é inadequada e não recomendável.

Embora a tutela penal do meio ambiente funcione como um instrumento de repressão aos agressores, Sirvinskas (2015) acredita que será a educação nos bancos escolares que fará despertar a consciência cívica dos povos, enfatizando que o meio ambiente não tem pátria, é de cada um, individualmente, e, ao mesmo tempo, de todos. Antes do advento da Lei n. 9.605/1998 (BRASIL, 1998), era complexo analisar as leis esparsas existentes. Ficava dificultosa a consulta rápida e imediata de toda a legislação dispersa existente no ordenamento penal. Por essa razão, foi necessária uma codificação ordenada e sistematizada das infrações penais ambientais, tendo a tutela penal do meio ambiente seu núcleo na Lei 9.605/1998, a chamada Leis dos Crimes Ambientais (SIRVINSKAS, 2015). 
A maioria dos delitos previstos na Lei 9.605/98 são crimes de menor potencial ofensivo, existindo a modalidade culposa nos Arts. 38, 40, 41, 49, 54, 62 e 68 (BRASIL, 1998). Segundo Amado (2014), poucos delitos não se sujeitam à substituição da pena privativa de liberdade pela restritiva de direito, a exemplo dos Arts. 35 e 40 da referida Lei, que constituem crimes de dano e de perigo ante o caráter irreparável dos danos ambientais. A coletividade sempre será sujeito passivo dos crimes ambientais, ainda que o delito afete algum membro da sociedade, a exemplo do desmatamento ilegal de floresta particular.

\section{AÇÃO PENAL AMBIENTAL}

O Poder Judiciário é responsável pela função jurisdicional, por meio da qual o Estado-Juiz aplica o direito objetivo à lide que lhe é apresentada e declara o direito aplicável. Portanto, caso haja um dano ao meio ambiente considerado crime, está-se diante de um fato passível de análise pelo Poder Judiciário que exercerá o seu poder de jurisdição e aplicará a lei penal ambiental (CINTRA et al., 1977).

O processo é um instrumento do Estado para o exercício da função jurisdicional. Segundo Barroso (2003, p. 3),

[...] o processo é o instrumento colocado à disposição dos cidadãos para solução de seus conflitos de interesses e pelo qual o Estado exerce a jurisdição. Tal solução e exercício são desenvolvidos com base nas regras legais previamente fixadas e buscam, mediante a aplicação do direito material em caso concreto, a entrega do bem da vida, a pacificação social e a realização da justiça.

A finalidade do processo, no que diz respeito à sua instrumentalidade, é realizar o direito e resolver os conflitos, eliminando-os. Caso não cumpra seu objetivo, o que efetivamente ocorre é que a jurisdição não concretiza os seus fins (ABREU, 2004). O meio jurisdicional de solução de uma lide ocorre por meio de um processo. De acordo com Gusmão (1934), o termo processo provém, etimologicamente, do latim processus, que significa avançar, seguir caminhando; porém, o sentido da palavra processo jurisdicional data dos últimos séculos da Idade Média. 
O processo é um instrumento com valor apenas quando serve ao direito material e aos escopos da jurisdição. O processo tem por objetivo a promoção da paz social, por meio da resolução de conflitos de interesses da sociedade e garantia da segurança jurídica de suas relações, além da conscientização dos direitos e das obrigações dos jurisdicionados e educação para o exercício deles (MARINONI, 1999).

Conforme preconiza o Art. 26 da Lei Ambiental n. 9.605/98 (BRASIL, 1998), todos os crimes nela tipificados são de ação penal pública incondicionada, cuja iniciativa é do Ministério Público (BRASIL, 1988, Art. 129, 1), permitindo a ação penal subsidiária da pública em caso de omissão do Ministério Público (BRASIL, 1988, Art. 5ํ, LXI; BRASIL, 1940, Art. 100, § 3ㅇ; BRASIL, 1941, Art. 29; BRASIL, 2013). Os procedimentos das ações penais ambientais são previstos no Código de Processo Penal (BASIL, 1941), e a competência ambiental será determinada em razão da matéria. Para julgar esses crimes, os procedimentos são, em regra, da Justiça Estadual, salvo se o delito for consumado contra bens, serviços ou interesse da União, de suas autarquias ou empresas públicas, conforme previsão do Art. 109, IV da Constituição Federal (BRASIL, 1988). Tem-se como exemplo que o crime praticado contra a flora é de competência da Justiça Federal, se a unidade de conservação pertencer à União, ou da Justiça Estadual, se pertencer aos estados e municípios (BRASIL, 1988).

\section{ABRANGÊNCIA, LEVANTAMENTO DE DADOS E PROSPECÇÃO BIBLIOGRÁFICA}

A pesquisa foi realizada no município de Rubiataba, localizado na microrregião de Ceres. Possui uma área territorial de $748,27 \mathrm{~km}^{2}$. A população total do município, em 2010 (último censo), era de 18.915 habitantes e uma densidade demográfica de 25,28, conforme dados do Instituto Brasileiro de Geografia e Estatística (IBGE, 2019). Rubiataba foi fundada em 1949, a partir do projeto da colônia agrícola estadual, implantado no Vale de São Patrício (GOIÁS, 2012; RUBIATABA, 2019).

Para a realização do trabalho, foi feita uma análise documental dos processos penais ambientais na Escrivania Criminal da Comarca de Rubiataba, GO, 
órgão do Tribunal de Justiça do Estado de Goiás, entre os meses de agosto de 2018 e setembro de 2019. Os dados foram obtidos considerando os crimes ambientais ocorridos, denunciados e julgados entre os anos de 2012 e 2018.

A análise dos autos foi realizada pelo método comparativo, recorrendo à Lei ambiental n. 9.605/98 (BRASIL, 1998), bem como à Lei 9.099/95 (BRASIL, 2007), que possibilita acordos e transações penais benéficas ao cumprimento das determinações estipuladas em Juízo. Foram abordados acordos pactuados entre as partes, disciplinados pela Lei retromencionada, considerando-se as decisões de arquivamento em cada caso e as revogações dos benefícios concedidos e não cumpridos pelas partes.

\section{CRIMES AMBIENTAIS OCORRIDOS NA COMARCA DE RUBIATABA, GO}

Foram registrados 23 processos criminais ambientais ocorridos entre os anos de 2012 e 2018. Ressalta-se que, em 2014, não foram registrados processos ou anotações sobre crimes ambientais em Rubiataba, GO. A maior incidência de crimes ambientais ocorreu no ano de 2017 (39,13\%), seguida do ano de 2018 (26,09\%) e 2016 (21,74\%). Nos anos de 2012, 2013 e 2015, verificou-se a existência de um processo de crime ambiental para cada ano (Figura 2).

Figura 1 - Número de processos criminais ambientais ocorridos na Comarca de Rubiataba, Goiás, entre os anos de 2012 e 2018

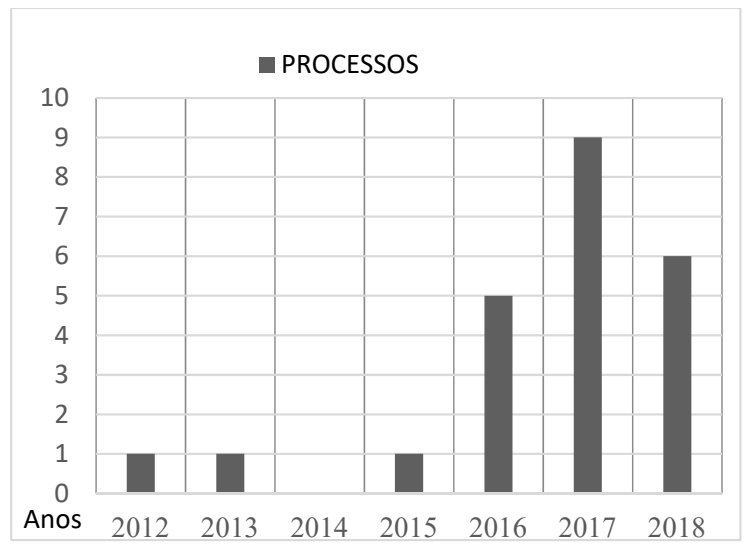

Fonte: Própria autora (2020). 
No período avaliado, constatou-se que nove crimes (40\%) estão associados ao Art. 38 da Lei Ambiental n. 9.605/1998 (BRASIL, 1998) que se refere ao ato de cortar árvores em florestas em área de preservação permanente, sem a permissão da autoridade competente (Figura 3).

Figura 2 - Incidência de infrações aos artigos da Lei Ambiental n. 9.605/ 1998, na Comarca de Rubiataba, Goiás, entre os anos de 2012 e 2018

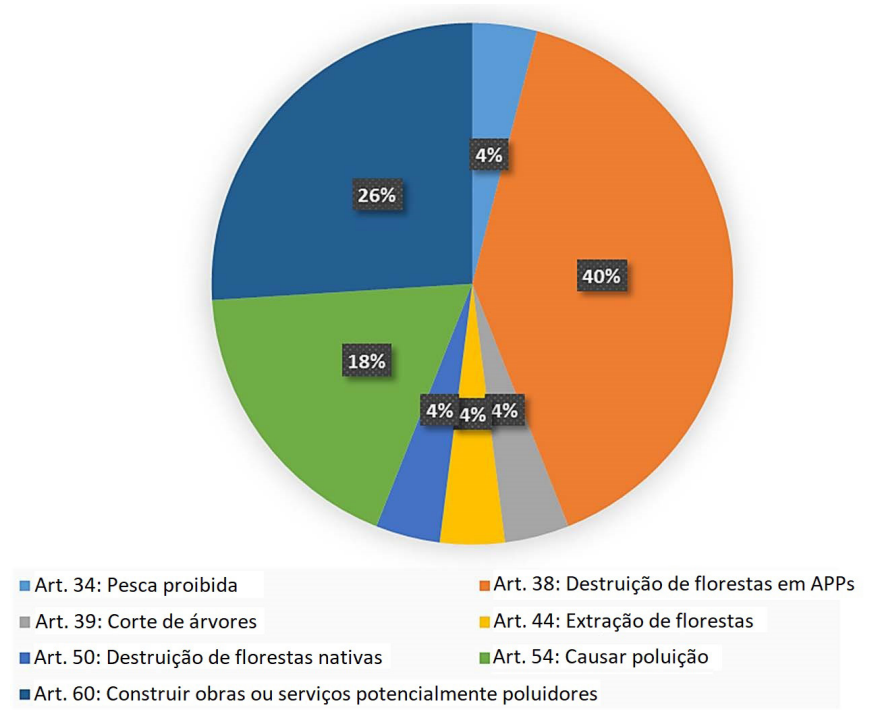

Fonte: Própria autora (2020).

A infração ambiental descrita no Art. 38 da Lei 9.605/98 tem como previsão de pena de 1 a 3 anos de reclusão e multa. Por se tratar de crime de conduta com pena mínima igual a um ano e preencher as demais condições do Art. 89, da Lei 9.099/95, houve, em quatro desses processos, proposta do benefício da suspensão condicional do processo por 2 anos, com proposta aceita. Em três desses processos, os beneficiados cumpriram as condições impostas no termo de audiência. Em um processo, o beneficiado não conseguiu cumprir as condições, com o benefício revogado pelo juiz e os autos retomando o curso normal. Entretanto, vislumbrou-se que os referidos autos estão prescritos, aguardando a decisão judicial. 
Verificou-se que quatro processos criminais (18\%), ocorridos entre 2012 e 2018, são caracterizados por infração do Art. 54 da Lei 9.605/98, referindo-se à poluição de qualquer natureza resultando em danos à saúde humana, ou que provoque a mortandade de animais ou a destruição significativa da flora. Nesses casos, é prevista pena de 1 a 4 anos de reclusão e multa. Dessas quatro infrações penais, apenas um processo teve o benefício da transação penal do Art. 76 da Lei 9.099/95, havendo o beneficiado cumprido as condições impostas. Apenas um desses processos aguarda o oferecimento de denúncia e o outro foi apensado a outros autos. Em setembro de 2018, os demais processos foram remetidos à Delegacia de Polícia para diligências.

Dos processos pesquisados, seis (26\%) incidiram nas sanções penais da Lei Ambiental n. 9.605/98. Os infratores construíram e reformaram represas, sem licença e sem autorização dos órgãos ambientais competentes, conforme o disposto na Lei n. 9.605/98:

[...] construir, reformar, ampliar, instalar ou fazer funcionar, em qualquer parte do território nacional, estabelecimentos, obras ou serviços potencialmente poluidores, sem licença ou autorização dos órgãos ambientais competentes, ou contrariando as normas legais e regulamentares pertinentes: Pena: detenção, de um a seis meses, ou multa, ou ambas as penas cumulativamente (BRASIL, 1998, Art. 60).

Desses processos associados ao Art. 60, em dois deles houve a proposta de transação penal do Art. 76 da Lei 9.099/95 (BRASIL, 2007), havendo sido aceita e cumprida pelos agressores, sendo os autos arquivados. Em dois processos, houve proposta de suspensão condicional da pena, prevista no Art. 89 da Lei 9.099/95, sendo aceita e cumprida pelos acusados. Outros dois processos se encontravam apensos a outros processos, sem julgamento do mérito. Os demais processos tiveram incidências penais nos Arts. 34, 39, 44 e 50 da Lei 9.605/98, todos com previsão de pena máxima inferior a 3 anos (BRASIL, 1998).

No desfecho desses processos, 1 obteve a concessão da suspensão condicional do processo e cumpriu as condições impostas e outro foi arquivado por falta de justa causa para a propositura da ação penal. Em outros 2 processos, o Ministério Público ofereceu denúncia e se aguardava 
A tutela jurisdicional dos crimes ambientais ocorridos na comarca de Rubiataba, Goiás, entre o período de 2012 a 2018

o prosseguimento do feito. Com exceção da pena aplicada ao Art. 54 da Lei 9.605/1998, em que a pena máxima é de 4 anos, todas as demais infrações penais têm pena máxima, em abstrato, inferior a 3 anos.

Corroborando a doutrina majoritária dos Tribunais, Amado (2014, p. 623) enfatiza que "[...] uma interpretação possível é que agora, nos crimes ambientais da Lei 9.605/98, o que vale para obter o benefício da suspensão condicional do processo é a pena mínima de 2 anos". Segundo Barreto, Araújo e Brito (2009), o Ministério Público é responsável por avaliar o resultado de todas as investigações e decidir se oferece denúncia, se pede o arquivamento ou se propõe a transação penal ou a suspensão condicional do processo, quando cabível.

O instituto da transação penal busca, de forma célere e informal, atingir uma solução rápida, consensual e satisfatória para o conflito em lugar de uma sentença penal condenatória, prevendo sua aplicação nos crimes ambientais, conforme o Art. 27 da Lei Ambiental (SILVA, 2011).

A Lei 9.605/1998 descreve que:

[...] nos crimes ambientais de menor potencial ofensivo, a proposta de aplicação imediata de pena restritiva de direitos ou multa, prevista no Art. 76 da Lei 9.099/95, de 27 de setembro de 1995, somente poderá ser formulada desde que tenha havido a prévia composição do dano ambiental, que trata o Art. 74 da mesma Lei, salvo em caso de comprovada impossibilidade (BRASIL, 1988, Art. 27).

A transação penal prevista no Art. 76 da Lei 9.099/95 (BRASIL, 2007) foi apresentada pelo representante do Ministério Público aos agressores do meio ambiente, em três processos criminais ambientais. $O$ juiz esclareceu a possibilidade da composição de danos e da aceitação da proposta de transação penal oferecida pelo Ministério Público. Os agressores aceitaram a proposta de transação penal, e o acordo foi homologado pelo juiz. Para cada acusado, foi atribuída a obrigação de reparar o dano, consistente no pagamento de $\mathrm{R} \$ 1.200,00$, parcelada essa quantia em seis vezes de $\mathrm{R} \$$ 200,00, cujos valores foram depositados na conta da Comarca, conforme consta nos autos. Posteriormente, esses valores foram revertidos em favor do Conselho de Segurança do Município, visando aprimorar o aparelhamento da Unidade Prisional da Comarca de Rubiataba. 
Nogueira (2003, p. 162) orienta que:

Através da transação penal o que se busca é evitar o processo condenatório, instrumento da ação penal condenatória. Desta forma, nos termos da lei, o Ministério Público, não sendo o caso de arquivamento e estando presentes os requisitos legais, tem o dever de efetuar a proposta da transação ao autor do fato.

Se a proposta do Ministério Público não fosse aceita pelo autor da infração, o processo seguiria o rito normal até a prolação da sentença. Como os acusados aceitaram as propostas, o juiz aplicou a pena restritiva de direitos, não gerou reincidência, sendo registrada apenas para impedir novamente o mesmo benefício no prazo de cinco anos. É importante ressaltar, nesses casos, que o autor do fato, ao aceitar a proposta de transação penal oferecida pelo promotor, não estará com isso reconhecendo a culpa pelo crime de que é acusado e, deste modo, não perderá sua condição de réu primário. Além disso, não constará anotação para fins de antecedentes criminais, salvo para impedir que o autor seja beneficiado com uma nova transação penal no prazo de 5 anos (BRASIL, 2007).

Conforme preconiza a Lei 9.099/95, "[...] a imposição da sanção de que trata o $\S 4$ deste artigo não constará de certidão de antecedentes criminais, salvo para os fins previstos no mesmo dispositivo, e não terá efeitos civis, cabendo aos interessados propor ação cabível no juízo cível" (BRASIL, 2007, Art. 72).

A proposta de suspensão condicional do processo foi oferecida em quatro processos criminais ambientais. Ressalte-se que o instituto da suspensão condicional do processo está previsto na Lei 9.099/95, que estabelece, como requisito para a sua concessão, uma pena mínima igual ou inferior a um ano para crimes abrangidos ou não pela lei (BRASIL, 2007, Art. 89). É necessário, ainda, que o acusado não esteja sendo processado ou não tenha sido condenado por outro crime. Se aplicado este instituto, o processo penal fica suspenso por 2 a 4 anos.

Se presentes os requisitos de aplicação da transação penal e da suspensão condicional do processo, não pode o membro do Ministério Público esquivar-se da sua aplicação (SILVA, 2011). Obrigatoriamente, deve apresentar a proposta de transação penal ou suspensão do processo, se 
A tutela jurisdicional dos crimes ambientais ocorridos na comarca de Rubiataba, Goiás, entre o período de 2012 a 2018

cabível, mesmo porque, estando tais institutos à disposição do provável infrator, tem ele o direito de receber os seus benefícios, não configurando, portanto, mera faculdade do Ministério Público. O Ministério Público é responsável por avaliar o resultado de todas as investigações e decidir se propõe ao juiz o início de ação penal ou o arquivamento do caso. Se decidir por promover a ação penal, o Ministério Público poderá propor transação penal, suspensão condicional do processo ou simplesmente o início da ação penal (BARRETO; ARAÚJO; BRITO, 2009).

Os resultados finais da análise dos processos de crimes ambientais que ocorreram na Comarca de Rubiataba, entre os anos de 2012 e 2018, são apresentados na Tabela 1.

Tabela 1 - Resultados da pesquisa realizada na Serventia Criminal da Comarca de Rubiataba, GO

\begin{tabular}{|c|c|c|c|}
\hline $\begin{array}{l}\text { Processo } \\
\text { Criminal } \\
\text { Ambiental }\end{array}$ & $\begin{array}{l}\text { Natureza } \\
\text { do Crime } \\
\text { Ambiental }\end{array}$ & $\begin{array}{c}\text { Tentativa de Acordo da } \\
\text { Lei 9.099/95 } \\
\text { Suspensão do Processo } \\
\text { ou transação penal }\end{array}$ & Resultado final \\
\hline $\begin{array}{l}\text { 351659-03 } \\
2012.8 .09 .0139\end{array}$ & $\begin{array}{l}\text { Art. 38, Lei } \\
9.605 / 98\end{array}$ & $\begin{array}{l}\text { Houve proposta e o } \\
\text { agressor aceitou a proposta } \\
\text { em 26/05/2015. Cumpriu } \\
\text { fielmente as condições. }\end{array}$ & $\begin{array}{l}\text { Arquivados os autos em } \\
\text { 24/08/2011. Extinta de } \\
\text { punibilidade. }\end{array}$ \\
\hline $\begin{array}{l}249215-52 \\
2013.8 .09 .0139\end{array}$ & $\begin{array}{l}\text { Art. 54, Lei } \\
9.605 / 98\end{array}$ & $\begin{array}{l}\text { Aceita a proposta de } \\
\text { suspensão condicional do } \\
\text { processo em } 21 / 04 / 2014 \text {. }\end{array}$ & $\begin{array}{l}\text { Em junho de 2016, } \\
\text { foi julgada extinta a } \\
\text { punibilidade, em razão da } \\
\text { morte do beneficiado. }\end{array}$ \\
\hline $\begin{array}{l}\text { 04843-55 } \\
\text { 2015.8.09.0139 }\end{array}$ & $\begin{array}{l}\text { Art. 38, Lei } \\
9.605 / 98\end{array}$ & $\begin{array}{l}\text { Não houve proposta de } \\
\text { suspensão do processo, } \\
\text { tendo em vista a morte do } \\
\text { acusado. }\end{array}$ & $\begin{array}{l}\text { Extinta a punibilidade, em } \\
\text { razão da morte do réu, em } \\
21 / 06 / 2016 \text {. }\end{array}$ \\
\hline $\begin{array}{l}377770-82 \\
2016.8 .09 .0139\end{array}$ & $\begin{array}{l}\text { Art. 60, Lei } \\
9.605 / 98\end{array}$ & $\begin{array}{l}\text { Decisão: apensamento aos } \\
\text { autos do inquérito de n. } \\
201702668570 .\end{array}$ & $\begin{array}{l}\text { Autos suspensos, } \\
\text { aguardando andamento dos } \\
\text { autos. }\end{array}$ \\
\hline $\begin{array}{l}163913-50 \\
2016.8 .09 .0139\end{array}$ & $\begin{array}{l}\text { Art. 44, Lei } \\
9.605 / 98\end{array}$ & $\begin{array}{l}\text { Havendo notícias de que } \\
\text { o acusado estava com } \\
\text { problemas mentais, foram } \\
\text { abertos autos de incidente } \\
\text { de insanidade mental. }\end{array}$ & $\begin{array}{l}\text { Aguardando a realização } \\
\text { de perícia pelo TJGO } \\
\text { nos autos de n. } 88056 \text { - } \\
\text { 27.2018.8.09.0139. }\end{array}$ \\
\hline
\end{tabular}




\begin{tabular}{|c|c|c|c|}
\hline $\begin{array}{l}\text { Processo } \\
\text { Criminal } \\
\text { Ambiental }\end{array}$ & $\begin{array}{l}\text { Natureza } \\
\text { do Crime } \\
\text { Ambiental }\end{array}$ & $\begin{array}{c}\text { Tentativa de Acordo da } \\
\text { Lei 9.099/95 } \\
\text { Suspensão do Processo } \\
\text { ou transação penal }\end{array}$ & Resultado final \\
\hline $\begin{array}{l}376190-17 \\
2016.8 .09 .0139\end{array}$ & $\begin{array}{l}\text { Arts. } 38 \text { e } \\
60, \text { da Lei } \\
9.605 / 98\end{array}$ & $\begin{array}{l}\text { Em 1/10/2018, houve } \\
\text { transação penal do art. } 76 \\
\text { da Lei } 9.099 / 95 \text {. Acordo: } \\
\text { doação de } \mathrm{R} \$ 1.200,00, \\
\text { parcelado em seis vezes, } \\
\text { na conta da Comarca. }\end{array}$ & $\begin{array}{l}\text { Estando o réu cumprindo o } \\
\text { acordo desde } 1 \text { o/10/2018, } \\
\text { posto que o referido valor } \\
\text { foi parcelado em seis vezes. }\end{array}$ \\
\hline $\begin{array}{l}377759-53 \\
2016.8 .09 .0139\end{array}$ & $\begin{array}{l}\text { Art. 60, Lei } \\
9.605 / 98\end{array}$ & 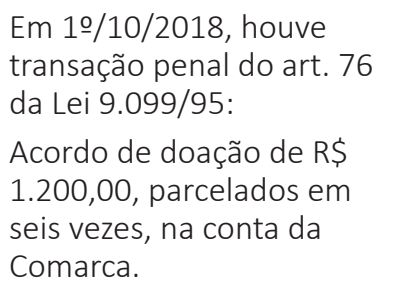 & $\begin{array}{l}\text { Estando o réu cumprindo o } \\
\text { acordo desde } 1 \text { o/10/2018, } \\
\text { posto que o referido valor } \\
\text { foi parcelado em seis vezes. }\end{array}$ \\
\hline $\begin{array}{l}376208- \\
382016.8 .09 .0139\end{array}$ & $\begin{array}{l}\text { Art. 60, Lei } \\
9.605 / 98\end{array}$ & $\begin{array}{l}\text { Aceita a proposta de } \\
\text { transação penal do art. } 76 \\
\text { da Lei } 9.099 / 95 \text {. }\end{array}$ & $\begin{array}{l}\text { Acordo realizado em } \\
31 / 08 / 2018 . \\
\text { Estava cumprindo as } \\
\text { condições da transação } \\
\text { penal. }\end{array}$ \\
\hline $\begin{array}{l}106963-84 \\
2017.8 .09 .0139\end{array}$ & $\begin{array}{l}\text { Art. 60, Lei } \\
9.605 / 98\end{array}$ & $\begin{array}{l}\text { Aceita a proposta de } \\
\text { suspensão condicional do } \\
\text { proc. em 03/04/2014. O } \\
\text { beneficiado não cumpriu o } \\
\text { acordo. }\end{array}$ & $\begin{array}{l}\text { Benefício revogado. } \\
\text { Processo em andamento. }\end{array}$ \\
\hline $\begin{array}{l}\text { 36932-39 } \\
\text { 2017.8.09.0139 }\end{array}$ & $\begin{array}{l}\text { Art. 54, Lei } \\
9.605 / 98\end{array}$ & $\begin{array}{l}\text { Não houve proposta. } \\
\text { Autos apensados } \\
\text { aos autos n. 106963- } \\
\text { 84.2017.8.09.0139. }\end{array}$ & $\begin{array}{l}\text { Aguardando oferecimento } \\
\text { de denúncia pelo Ministério } \\
\text { Público. }\end{array}$ \\
\hline $\begin{array}{l}\text { 202413-54 } \\
\text { 2017.8.09.0139 }\end{array}$ & $\begin{array}{l}\text { Art. 54, Lei } \\
9.605 / 98\end{array}$ & $\begin{array}{l}\text { Não houve proposta de } \\
\text { suspensão condicional do } \\
\text { processo. }\end{array}$ & $\begin{array}{l}\text { Autos remetidos à } \\
\text { Delegacia de Polícia Civil, } \\
\text { para diligências. }\end{array}$ \\
\hline $\begin{array}{l}\text { 32713-96 } \\
\text { 2017.8.09.0139 }\end{array}$ & $\begin{array}{l}\text { Art. 38, Lei } \\
9.605 / 98\end{array}$ & $\begin{array}{l}\text { A denúncia não foi } \\
\text { recebida, falta de justa } \\
\text { causa para a ação penal. }\end{array}$ & $\begin{array}{l}\text { Arquivados os autos em } \\
29 / 01 / 2019 .\end{array}$ \\
\hline $\begin{array}{l}266857-96 \\
2017.8 .09 .0139\end{array}$ & $\begin{array}{l}\text { Art. 60, Lei } \\
9.605 / 98\end{array}$ & $\begin{array}{l}\text { TCO em andamento } \\
\text { apensos aos autos de n. } \\
201603777703 \text {. }\end{array}$ & $\begin{array}{l}\text { Autos conclusos em } \\
\text { 19/12/2018 para a } \\
\text { deliberação acerca do } \\
\text { recebimento ou não da } \\
\text { denúncia. }\end{array}$ \\
\hline
\end{tabular}




\begin{tabular}{|c|c|c|c|}
\hline $\begin{array}{l}\text { Processo } \\
\text { Criminal } \\
\text { Ambiental }\end{array}$ & $\begin{array}{l}\text { Natureza } \\
\text { do Crime } \\
\text { Ambiental }\end{array}$ & $\begin{array}{c}\text { Tentativa de Acordo da } \\
\text { Lei 9.099/95 } \\
\text { Suspensão do Processo } \\
\text { ou transação penal }\end{array}$ & Resultado final \\
\hline $\begin{array}{l}164690-98 \\
2017.8 .09 .0139\end{array}$ & $\begin{array}{l}\text { Art. 54, Lei } \\
9.605 / 98\end{array}$ & $\begin{array}{l}\text { Não houve proposta de } \\
\text { suspensão condicional ou } \\
\text { transação penal. }\end{array}$ & $\begin{array}{l}\text { Aguardando oferecimento } \\
\text { de denúncia pelo Ministério } \\
\text { Público. }\end{array}$ \\
\hline $\begin{array}{l}54260-79 \\
2017.8 .09 .0139\end{array}$ & $\begin{array}{l}\text { Art. 39, Lei } \\
9.605 / 98\end{array}$ & $\begin{array}{l}\text { A denúncia foi recebida. } \\
\text { Não houve proposta de } \\
\text { benefício. }\end{array}$ & $\begin{array}{l}\text { Aguardando designação de } \\
\text { audiência preliminar. }\end{array}$ \\
\hline $\begin{array}{l}10850-84 \\
2017.8 .09 .0139\end{array}$ & $\begin{array}{l}\text { Art. 38, Lei } \\
9.605 / 98\end{array}$ & $\begin{array}{l}\text { Inquérito Policial, ainda } \\
\text { não havia denúncia. }\end{array}$ & $\begin{array}{l}\text { Os autos foram remetidos } \\
\text { à Delegacia de Polícia } \\
\text { Local para Diligências em } \\
\text { 10/10/2018. }\end{array}$ \\
\hline $\begin{array}{l}66165-97 \\
2017.8 .09 .0139\end{array}$ & $\begin{array}{l}\text { Art. 60, Lei } \\
9.605 / 98\end{array}$ & $\begin{array}{l}\text { O Ministério Público } \\
\text { alegou falta de justa causa } \\
\text { para oferecer a denúncia. }\end{array}$ & $\begin{array}{l}\text { O acusado estava sendo } \\
\text { julgado nos autos } \\
201603762080 \text {. Autos } \\
\text { arquivados em 14/06/2018. }\end{array}$ \\
\hline $\begin{array}{l}2336-92 \\
2018.8 .09 .0139\end{array}$ & $\begin{array}{l}\text { Art. 38, Lei } \\
9.605 / 98\end{array}$ & $\begin{array}{l}\text { O Ministério Público } \\
\text { alegou falta de justa causa } \\
\text { para oferecer a denúncia. }\end{array}$ & $\begin{array}{l}\text { O acusado sendo julgado } \\
\text { nos autos } 201603761904 . \\
\text { Autos arquivados em } \\
\text { 05/07/2018. }\end{array}$ \\
\hline $\begin{array}{l}2331-70 \\
2018.8 .09 .0139\end{array}$ & $\begin{array}{l}\text { Art. 50, Lei } \\
9.605 / 98\end{array}$ & $\begin{array}{l}\text { A denúncia não foi } \\
\text { recebida, falta de justa } \\
\text { causa para a ação penal. }\end{array}$ & $\begin{array}{l}\text { Arquivados os autos em } \\
26 / 04 / 2018 \text {. }\end{array}$ \\
\hline $\begin{array}{l}4776-61 \\
2018.8 .09 .0139\end{array}$ & $\begin{array}{l}\text { Art. 34, Lei } \\
9.605 / 98\end{array}$ & $\begin{array}{l}\text { Foi proposta a Suspensão } \\
\text { Condicional do Processo, } \\
\text { por } 2 \text { anos. Aceita pelo réu } \\
\text { em } 22 / 10 / 2018 \text {. }\end{array}$ & $\begin{array}{l}\text { Até } 28 / 12 / 2018, \text { o } \\
\text { beneficiado estava } \\
\text { cumprindo o período de } \\
\text { prova. }\end{array}$ \\
\hline $\begin{array}{l}58196-78 \\
2018.8 .09 .0139\end{array}$ & $\begin{array}{l}\text { Art. 38, Lei } \\
9.605 / 98\end{array}$ & $\begin{array}{l}\text { Ainda não foi proposta } \\
\text { ao réu. Em 19/09/2018, } \\
\text { foram os autos remetidos } \\
\text { à Delegacia de Polícia para } \\
\text { diligências. }\end{array}$ & $\begin{array}{l}\text { Remetido à Delegacia de } \\
\text { Polícia Civil em 05/10/2018. }\end{array}$ \\
\hline $\begin{array}{l}117514-89 \\
2018.8 .09 .0139\end{array}$ & $\begin{array}{l}\text { Art. 38, Lei } \\
9.605 / 98\end{array}$ & Não houve proposta. & $\begin{array}{l}\text { Remetido à Delegacia de } \\
\text { Polícia Civil em 05/10/2018. }\end{array}$ \\
\hline $\begin{array}{l}119213-18 \\
2018.8 .09 .0139\end{array}$ & $\begin{array}{l}\text { Art. 38, Lei } \\
9.605 / 98\end{array}$ & Não houve proposta. & $\begin{array}{l}\text { Remetido à Delegacia de } \\
\text { Polícia Civil em 05/10/2018. }\end{array}$ \\
\hline
\end{tabular}

Fonte: Própria autora (2020). 
Nos autos dos processos de n. 351659-03.2012.8.09.0139, 37777082.2016.8.09.0139, 376190-17.2016.8.090139, 377759-53.2016.8.09.0139 e 4776-61.2018.8.090139, os beneficiados aceitaram as propostas de transação e suspensão condicional do processo e cumpriram as condições impostas. Conforme registrado em 2016, dos cinco processos constatados, três aceitaram a proposta de transação penal do Art. 76 da Lei 9.099/95 e cumpriram as medidas a eles impostas, sendo, posteriormente, extinta a punibilidade pelo cumprimento da pena e arquivados os autos.

Nos autos de n. 249215-52.2013.8.09.0139 e 304843-55.2015.8090139, antes do cumprimento das condições, ocorreu a morte dos acusados, sendo julgada extinta a punibilidade pela morte dos agentes, conforme se pode ver da Tabela 1. No ano de 2017, dos nove processos analisados, apenas dois tiveram proposta do benefício da suspensão condicional do processo prevista no Art. 89 da Lei 9.099/95. Somente um cumpriu as condições impostas no acordo feito em audiência, conforme adiante será mais bem explicado.

Assim, dos processos analisados, quatro foram arquivados por falta de justa causa para a propositura da ação penal. Nos autos n. 26616597.2017.8.09.0139, o indiciado era investigado por suposta prática tipificada no Art. 38 da Lei 9.605/1998, tendo cortado oito árvores da espécie denominada "cega-machado", no sítio Grotão, localizado na zona rural de Rubiataba, GO. A decisão fundamentou-se no fato de que as árvores não estavam em área de preservação permanente e, por isso, não havia os elementos típicos descritos no Art. 38 da Lei 9.605/1998. Não houve justa causa para o prosseguimento da persecução penal, deixando o juiz de receber a denúncia e determinando o arquivamento dos autos em dezembro de 2018.

Nos autos n. 232713-96.2017.8.09.0139, houve denúncia pelo representante do Ministério Público. Entretanto, a denúncia não foi recebida pelo juiz que se fundamentou na falta de justa causa para a propositura da ação penal, e os autos foram arquivados em 2018.

Nos autos n. 2336-92.2018.8.090139, incidência no Art. 38 da Lei 9.605/98, constatou-se que o representante do Ministério Público alegou falta de justa causa para oferecer a denúncia, dizendo não restarem provados a materialidade e os indícios de autoria. O acusado era julgado nos autos 201603761904 pelo mesmo fato, por isso, os autos foram 
A tutela jurisdicional dos crimes ambientais ocorridos na comarca de Rubiataba, Goiás, entre o período de 2012 a 2018

arquivados em $05 / 07 / 2018$. No ano de 2018 , verificaram-se os autos 4776 61.2018.8.09.0139 com incidência ao Art. 34 da Lei 9.605/98, a saber:

Art. 34. Pescar em período no qual a pesca seja proibida ou em lugares interditados por órgão competente:

Pena- detenção de um ano a três anos ou multa, ou ambas as penas cumulativamente.

Parágrafo único. Incorre nas mesmas penas quem:

I - pesca espécies que devam ser preservadas ou espécimes com tamanhos inferiores aos permitidos;

II- pesca quantidades superiores às permitidas, ou mediante a utilização de aparelhos, petrechos, técnicas e métodos não permitidos; III - transporta, comercializa, beneficia ou industrializa espécimes provenientes da coleta, apanha e pesca proibidas (BRASIL, 1998).

A proposta de suspensão condicional do processo foi feita, ficando o acusado comprometido a fazer a doação de R\$ 954,00 em favor do fundo de recursos da comarca de Rubiataba, valor que poderá ser pago em seis parcelas de $\mathrm{R} \$ 159,00$.

Nos demais processos em que aceitaram a proposta e cumpriram integralmente as condições, os acusados/beneficiados efetuaram o depósito da quantia de $\mathrm{R} \$ 1.200,00$ cada um, como ocorreu nos autos de $n$. 377759-53.2016.8.09.0139, que incorreu nos Arts. 38 e 60 da Lei 9.605/98, consistente no fato de que o agressor reformou e ampliou represa de $120 \mathrm{~m}^{2}$, atingindo a Área de Preservação Ambiental, no ano 2016. Em 1ㅇ/10/2018, houve transação penal do Art. 76 da Lei 9.099/95, consistente no acordo de doação de $\mathrm{R} \$ 1.200,00$, parcelados em seis vezes, na conta da Comarca. Nos autos n. 376190-17.2016.8.09.0139, com incidência ao Art. 38 e 60 da Lei 9605/98, o indiciado reformou e ampliou represa de $150 \mathrm{~m}^{2}$, atingindo a

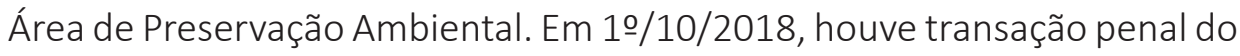
Art. 76 da Lei 9.099/95, consistente no acordo de doação de R\$ 1.200,00, parcelados em seis vezes.

O maior valor de pena pecuniária a título de reparação do dano ocorreu nos autos de n. 351659-03.2012.8.09.0139, incidência ao Art. 38 da Lei n. 9.605/98, com proposta de suspensão condicional do processo por 2 anos e de o agressor cumprir todas as condições impostas, dentre elas, 
o pagamento do valor de $\mathrm{R} \$ 5.000,00$, depositados na conta da Comarca. Em 24/08/2017, os autos foram arquivados com decisão de extinção da punibilidade, por haver o beneficiado cumprido, integralmente, as condições que lhes foram impostas.

Todos os valores depositados na conta da Comarca de Rubiataba foram revertidos em favor do aparelhamento da unidade prisional da Cidade de Rubiataba. Os beneficiados que aceitaram as propostas e cumpriram as condições tiveram decisão de extinção da punibilidade devido ao cumprimento das condições, e os autos foram arquivados logo em seguida, não registrando antecedentes criminais contra o beneficiado.

O único caso de revogação do benefício ocorreu nos autos n. 10696384.2017.8.09.0139, em que o beneficiado não cumpriu as condições impostas. Ressalte-se que a suspensão será revogada se, no curso do prazo, o beneficiário vier a ser processado por outro crime ou não efetuar, sem motivo justificado, a reparação do dano, previsão do § 3o, do Art. 89, da Lei n. 9.099/1995, retomando os autos o curso normal. Conforme previsão do Art. 89, §§ 3o e 4o da Lei 9.099/95 (BRASIL, 2007):

[...] nos crimes em que a pena mínima cominada for igual ou inferior a um ano, abrangidas ou não por esta Lei, o Ministério Público, ao oferecer a denúncia, poderá propor a suspensão do processo, por dois a quatro anos, desde que o acusado não esteja sendo processado ou não tenha sido condenado por outro crime, presentes os demais requisitos que autorizariam a suspensão condicional da pena (Art. 77 do Código Penal).

§ 3 A suspensão será revogada se, no curso do prazo, o beneficiário vier a ser processado por outro crime ou não efetuar, sem motivo justificado, a reparação do dano.

§ 4 A suspensão poderá ser revogada se o acusado vier a ser processado, no curso do prazo, por contravenção, ou descumprir qualquer outra condição imposta.

A investigação policial foi iniciada nos autos n. 10696384.2017.8.09.0139, incursos no Art. 60 da Lei Ambiental n. 9.605/98, em 18/11/2009. Foi registrada pela Delegacia Estadual de Repressão a Crimes contra o Meio Ambiente em Goiânia, remetida e distribuída à 2a Câmara Criminal do Tribunal de Justiça de Goiás, por se tratar de foro privilegiado, 
A tutela jurisdicional dos crimes ambientais ocorridos na comarca de Rubiataba, Goiás, entre o período de 2012 a 2018

uma vez que o acusado exercia o cargo de Prefeito Municipal de Morro Agudo de Goiás, e o crime ocorreu naquela localidade.

Em 12/05/2011, foi determinado pelo Tribunal de Justiça de Goiás que fossem os autos remetidos à Comarca de Rubiataba para a proposta de Suspensão Condicional do Processo, prevista no Art. 89 da Lei 9.099/95 ao acusado, então prefeito de Morro Agudo de Goiás. No dia 29/08/2011, o acusado não compareceu à audiência, havendo a defesa solicitado o prazo de 90 dias para juntar aos autos a comprovação do cumprimento do Termo de Ajustamento de Conduta (TAC), o que foi deferido pelo juiz. Registrou-se que, até o dia 11/04/2012, o acusado não havia juntado aos autos o TAC, havendo o Juiz determinado a devolução dos autos ao Tribunal de Justiça para prosseguimento.

Em 19/11/2012, o Ministério Público de Goiás ofereceu denúncia e relatou que o prefeito da Cidade de Morro Agudo de Goiás, GO, Distrito Judiciário da Comarca de Rubiataba, GO, à época, mantinha em funcionamento naquele Município um "lixão em área aberta", no qual eram despejadas, em média, 1,5 tonelada de lixo urbano produzido por dia pela população do Município, sem licença da Secretaria Estadual do Meio Ambiente e Recursos Hídricos (SEMARH), causando prejuízos ao meio ambiente, como a proliferação de vetores de doenças, especialmente roedores capazes de transmitir doenças infecciosas, além de insetos veiculadores de doenças e a decomposição dos resíduos provocarem a poluição do ar e a contaminação do solo e das águas.

Em 03/04/2014, em audiência, foi formulada pelo Ministério Público a proposta de Suspensão Condicional do Processo, prevista no Art. 89 da Lei 9.099/95, pelo prazo de 2 anos, mediante o cumprimento de condições:

1) - Reparação integral, até o final de 02 anos, do dano ambiental causado, inclusive com a comprovação de que o lixo urbano produzido no Município fosse depositado em aterro sanitário em conformidade com a Legislação Ambiental;

2) - Apresentação do laudo de constatação de reparação do dano ambiental a fim de que fosse possibilitado a extinção da punibilidade, nos termos do art. 28, I da Lei 9.605/98;

3)- Caso o Município já disponha de Lei provendo a contratação temporária de servidores por excepcional interesse público no âmbito 
do Poder Executivo que seja realizada a contratação temporária, no prazo de 60 (sessenta) dias, de profissional legalmente habilitado com ART (Anotação de Responsabilidade Técnica) para gerir o local de disposição final dos resíduos sólidos daquele Município de Morro Agudo de Goiás;

4) - Caso a Lei de Contratação temporária ainda não tivesse sido editada, que fosse realizada no prazo de 30 (trinta) dias a contratação direta por dispensa de licitação prevista no Art. 24 da Lei 8.666/93 de profissional legalmente habilitado com ART (Anotação de Responsabilidade Técnica) para, então, gerir o local de disposição final de resíduos sólidos naquele Município;

5)- Encaminhar Projeto de Lei à Câmara Municipal para a criação de cargo efetivo de Gestor de Resíduos Sólidos, com ART (Anotação de Responsabilidade Técnica) no prazo de 60(sessenta) dias;

6)- Providenciar a capacitação de um servidor do Município, preferencialmente efetivo, a respeito da instrução Normativa n. 05/2010 da SEMARH;

7)- Implantar, no prazo de 180 (cento e oitenta) dias, um programa de Coleta Seletiva no Município, por meio da separação dos resíduos em dois recipientes (lixo úmido/orgânico e seco reciclável), programa a ser instituído mediante a nomeação de servidor responsável, com a participação de cooperativas ou outras formas de associação de catadores de materiais reutilizáveis e recicláveis formados por pessoas físicas e de baixa renda, cuja contratação é dispensável de licitação, nos termos do art. 24, inciso XXVII da Lei 8.666/93;

8) - Implantar, no prazo de 60 (sessenta) dias, um programa de educação ambiental no Município com a finalidade de conscientizar a população sobre a necessidade de ações de redução, reaproveitamento e reciclagem dos resíduos sólidos;

9)- Criar e implementar, até o final do período de prova (02 anos) com o órgão municipal a Política Municipal do Meio Ambiente e,

10)- Finalmente, caso o acusado porventura deixe de exercer o cargo de Prefeito do Município, que compareça pessoalmente e obrigatoriamente, uma vez por mês na Serventia Criminal a fim de informar e justificar suas atividades (fls. 454 dos autos 106963-84.2017.8.09.0139, comarca de Rubiataba-GO em 03/04/2014).

Em 02/03/2016, foi o beneficiado intimado a comprovar o cumprimento das condições impostas no acordo. Entretanto, em 25/04/2016, às fls. 455/459, o acusado informou que não havia construído o Aterro Sanitário, 
alegando que a licença não havia sido deferida pelo Órgão Ambiental. Na oportunidade, o beneficiado solicitou a prorrogação do prazo de mais 1 (um) ano para cumprir as condições. Os autos foram remetidos ao Tribunal de Justiça para o deferimento, posto que, à época, o beneficiado exercia o cargo de Prefeito daquele Município do Morro Agudo de Goiás e tinha foro privilegiado e, por essa razão, os autos tramitavam no Tribunal de Justiça de Goiás, em Goiânia, GO. Em 06/03/2017, foram os autos remetidos à Comarca de Rubiataba, pois o acusado já não exercia mais o cargo de Prefeito, podendo ser julgado pelo Juiz da Comarca de Rubiataba, GO.

Decorridos mais de 3 anos, o acusado ainda não havia iniciado as obras para a construção do Aterro Sanitário naquele município. Em 23/07/2017, o Juiz da Comarca de Rubiataba, que proferiu decisão revogando o benefício da Suspensão Condicional do Processo e determinando o prosseguimento normal dos autos da Ação Penal, designou audiência para 28/05/2019. Registrou-se que, em dezembro de 2018, data da coleta de dados da presente pesquisa, nenhum aterro sanitário havia sido iniciado para receber o lixo produzido pelos moradores da Cidade de Morro Agudo de Goiás.

Ressalta-se que os moradores do Município de Morro Agudo de Goiás fizeram um movimento, denominado "abaixo assinado", para que, junto ao representante do Ministério Público, promovesse ação própria visando à construção do Aterro Sanitário na cidade, conforme informação constante dos autos do Inquérito Policial de n. 36932-39.2017.8.09.0139 tramitando no Fórum de Rubiataba, GO.

Registrou-se que os autos de n. 36932-39.2017.8.09.0139, incurso nas iras do Art. 54 da Lei 9.605/98, originaram-se do abaixo-assinado dos Moradores da Cidade de Morro Agudo de Goiás, enviado ao Ministério Público solicitando que o Prefeito Municipal da atual gestão construísse o aterro sanitário. A título de informação da pesquisa, constatou-se que, até aquela data, o aterro sanitário não havia sido construído por nenhum gestor do Município de Morro Agudo de Goiás. Há registro, também, de que não foi feita proposta de suspensão condicional do processo (Art. 89, da Lei 9.099/95) ao acusado. Além disso, os autos estavam apensados aos autos n. 106963-84.2017.8.09, aguardando oferecimento de denúncia, se for o caso. 
Ao analisar as situações dos dois processos, não foi constatado caso de conexão entre as duas situações, posto que os autos n. 06963-84.2017.8.09 tratam de denúncia contra o antigo prefeito. Entretanto, os autos de inquérito policial de n. 36932-39.2017.8.09.0139 registraram outro fato da atual gestão que não construiu o Aterro Sanitário, gerando vários problemas à população daquela cidade, em razão do lixo jogado a céu aberto. Desta forma, não se verificou, em nenhum processo, que a pena pecuniária aplicada fosse revertida em favor do meio ambiente degradado.

\section{CONSIDERAÇÕES FINAIS}

Foi possível identificar 23 processos criminais ambientais em trâmite na Comarca de Rubiataba entre os anos de 2012 e 2018. Identificou-se que oito processos analisados tiveram os benefícios da Lei 9.099/95, consistentes na transação penal e na suspensão condicional do processo, previstas nos Art. 76 e 89 da Lei 9.099/95. Apenas sete cumpriram os acordos e tiveram a extinção do processo pelo cumprimento dos acordos. Houve a revogação do benefício em um processo, posto que o beneficiado não cumpriu as condições a ele impostas.

Ressalte-se que quatro desses processos foram arquivados por falta de justa causa para a propositura da ação e por decreto de extinção da punibilidade. A requerimento ministerial, foi determinada a remessa de cinco processos à Delegacia de Polícia, para diligências.

De um lado, é um resultado positivo, pois demonstra a aplicação da transação penal em oito processos, como forma de agilizar a prestação jurisdicional. Por outro lado, é preocupante, pois ficou demonstrado que dois processos foram arquivados pela ocorrência da prescrição, tendo em vista a extinção da punibilidade. Além disso, constatou-se, à época da pesquisa, que existiam processos de inquéritos policiais aguardando oferecimento de denúncia pelo Ministério Público. Outra preocupação é que as penas pecuniárias ofertadas pelo Ministério Público foram ínfimas e destinadas a fins diversos, ou seja, não foram destinadas ao meio ambiente degradado.

A maior incidência de crimes ocorreu nas iras do Art. 38 da Lei 9.605/98, seguida do Art. 60 da referida Lei. Além da incidência, também, 
A tutela jurisdicional dos crimes ambientais ocorridos na comarca de Rubiataba, Goiás, entre o período de 2012 a 2018

do Art. 54, as demais ocorrências infracionais incidiram nos Arts. 34, 39, 44 e 50, sucessivamente, todos da mencionada Lei Ambiental. Ficou evidente que o oferecimento da transação penal nos crimes ambientais propõe a restrição de direito em prestações de serviço destinadas a entidades beneficentes que não se relacionam com a preservação ambiental.

Apesar da falta de relação entre o bem jurídico lesado e a entidade beneficiada, é importante frisar que o promotor de justiça agiu conforme o Art. 12 da Lei 9.605/98, posto que os valores atribuídos aos agressores foram pagos e, de alguma forma, aplicados a outras instituições que também necessitavam de ajuda. O Ministério Público, na condição de legitimado privativo da propositura da ação penal, na Comarca de Rubiataba, exerce influência de peso na concretização da responsabilização por crime ambiental e tem o dever legal de primar pela proteção e recuperação do meio ambiente, nos termos do Art. 129 de Constituição Federal de 1988. Salienta-se que as penas pecuniárias foram revertidas em favor do aparelhamento do Conselho Municipal de Segurança de Rubiataba, GO.

Diante do exposto, constata-se a necessidade da criação do Juizado Criminal Ambiental para que o Ministério Público possa atuar ante o Executivo nas implementações de políticas públicas ambientais, bem como na fiscalização efetiva das infrações ambientais, visando à proteção do meio ambiente na cidade de Rubiataba, GO.

\section{REFERÊNCIAS}

ABREU, P. M. Acesso à justiça e juizados especiais: o desafio histórico da consolidação de uma justiça cidadã no Brasil. Florianópolis: Fundação Boiteux, 2004.

AMADO, F. A. T. Direito ambiental esquematizado. 5. ed. Rio de Janeiro: Forense; São Paulo: Método, 2014.

ARAÚJO, L. C. Formação territorial do município de Rubiataba (GO): colônia agrícola, rede urbana e atividade sucroalcooleira (1950-2012). Ateliê Geográfico, Goiânia, GO, v. 7, n. 2, p.196-212, ago. 2013.

BARRETO, P.; ARAÚJO, E.; BRITO, B. A impunidade de crimes ambientais em áreas protegidas federais na Amazônia. Belém, PA: Instituto do Homem e Meio Ambiente da Amazônia, 2009. 56 p. ISBN: 978-85-86212-27-7. Disponível em: 
http://www.mma.gov.br/estruturas/225/_arquivos/12___a_impunidade_de_ crimes_ambientais_em_reas_protegidas_federais_na_amaznia_225.pdf. Acesso em: 13 jan. 2020.

BARROSO, C. E. F. M. Teoria geral de processo e processo de conhecimento. São Paulo: Saraiva, 2003.

BITENCOURT, C. R. Tratado de Direito Penal: parte geral. 1. ed. rev. ampl. atual. São Paulo: Saraiva, 2015.

BRASIL. Código Penal [1940] e Código de Processo Penal [1941]. 6. ed. atual. Porto Alegre: Tribunal de Justiça do Estado do Rio Grande do Sul / Departamento de Artes Gráficas, 2013. 221 p.

BRASIL. Lei n. 9.099, de 26 de setembro de 1995. Dispõe sobre os juizados especiais cíveis e criminais e dá outras providências. 4. ed. atual. e ampl. São Paulo: Saraiva, 2007. [Vade mecum].

BRASIL. Lei Federal n. 9.605, de 12 de fevereiro de 1998. Dispõe sobre as sanções penais e administrativas derivadas de condutas e atividades lesivas ao meio ambiente, e dá outras providências. Diário Oficial da União, 13 fev. 1998, Brasília, DF, Presidência da República, 1998.

BRASIL. Constituição da República Federativa do Brasil. Brasília, DF: Senado Federal, 1988.

BRASIL. Lei n. 6.938, de 31 de agosto de 1981. Dispõe sobre a Política Nacional do Meio Ambiente, seus fins e mecanismos de formulação e aplicação, e dá outras providências. Diário Oficial da União, 2 set. 1981, Seção 1, p. 16509, Brasília, DF, Presidência da República, 1981.

BRASIL. Decreto-lei 3689/41, de 3 de outubro de 1941. Código Processo Penal. Rio de Janeiro: Presidência da República, 1941.

BRASIL. Decreto-Lei n. 2.848, de 7 de dezembro de 1940. Código Penal. Rio de Janeiro: Presidência da República, 1940.

CINTRA, A. C. A.; GRINOVER, A. P.; DINAMARCO, C. R. CHIOVENDA, G. Princípios de derecho procesal civil. Madri: Reus, 1977.

FERREIRA, I. S. Tutela penal do patrimônio cultural. São Paulo: RT, 1995. [Biblioteca de Direito Ambiental]. 
A tutela jurisdicional dos crimes ambientais ocorridos na comarca de Rubiataba, Goiás, entre o

GIL, A. C. Como elaborar projetos de pesquisa. São Paulo: Atlas, 2002.

GOIÁS (estado). Secretária de Gestão e Planejamento do Estado de Goiás. Regiões de planejamento: 2011. Goiânia: SEGPLAN, 2012. 237 p.

GUSMÃO, M. A. Processo civil e comercial. 3. ed. São Paulo: Saraiva, 1934.

INSTITUTO BRASILEIRO DE GEOGRAFIA E ESTATÍSTICA [IBGE]. Rubiataba: cidades, trabalho e rendimento (censo 2010). Portal do IBGE, Rio de Janeiro, 2010. Disponível em: https://cidades.ibge.gov.br/brasil/go/rubiataba/panorama. Acesso em: 13 jan.2019.

INSTITUTO BRASILEIRO DE GEOGRAFIA E ESTATÍSTICA [IBGE]. Enciclopédia dos municípios brasileiros. Rio de Janeiro: IBGE, 1958.

MARINONI, L. G. Novas linhas de processo civil. 3. ed. rev. e ampl. São Paulo: Malheiros, 1999.

NOGUEIRA, M. F. Transação penal. São Paulo: Malheiros, 2003.

PAULA, M. C.; SILVA, C. M.; CORDEIRO, F. H. Impactos das políticas públicas e a importância da Cooper-Rubi no desenvolvimento de Rubiataba no Estado de Goiás. Estudos, Goiânia, GO, v. 34, n. 9/10, p. 735-64, set./out. 2007.

RUBIATABA, GO. História de Rubiataba. Disponível em: https://www.rubiataba. go.gov.br/pagina/181-historia-de-rubiataba. Acesso em: 28 jan. 2020.

SILVA, J. A. Direito ambiental constitucional. 11. ed. São Paulo: Malheiros, 2019.

SILVA, M. V. A utilização da transação penal e da suspensão do processo nos crimes ambientais. Revista Jus Navigandi, Teresina, ano 16, n. 2879, maio 2011. ISSN 15184 862. Disponível em: https://jus.com.br/artigos/19152. Acesso em: 9 fev. 2020.

SIRVINSKAS, L. P. Manual de direito ambiental. 13. ed. São Paulo: Saraiva, 2015. 
